\title{
THE EFFECT OF TELEVISION PROGRAM ON CHILDREN'S FOREIGN LANGUAGE ACQUISITION
}

\author{
Muhammad Rajulain \\ MAN 1 Kota Bima \\ email: rajulain@madrasah.id
}

\begin{abstract}
(Title: The Effect of Television Program on Children's Foreign Language Acquisition). Since it was first discovered in the 1920s, television has become an integral part of modern human life. The influence of television programs or programs on children's foreign language acquisition has become an interesting research subject to study. This study aims to determine the effect of television programs on the acquisition of foreign languages in a subject aged two years and three months using a qualitative method where the researcher also acts as an observer. The data obtained is recorded in the form of a diary, and interviews are conducted with parents and the people closest to the subject to obtain accurate data. The results of the study showed that the television programs being watched did not have a significant effect on the acquisition of foreign languages on the subjects studied.
\end{abstract}

Keywords: Television programs, foreign language acquisition, children

\section{INTRODUCTION}

Among many creatures in the world, human is the only species given the ability to speak for their communication. Although other creatures, such us animals also have the ability to communicate with others to meet their needs, they do not employ language(s) in their communication process. Humans are enabled with so-called linguistic capacity. Without having this capacity, the social life of our society will be slightly different (Kraus \& Chiu, 1997, p. 4)

In explaining how human beings are able to speak and employ language in daily life, one of the leading linguists, Chomsky (2000, p. 4)proposes a term "faculty of language' which he believes as the unique properties of human beings allowing us to produce and understand a particular language. Furthermore, he also states this "faculty of language" as an invisible language organ of human beings that is as important as other organs in our body such as lungs, heart, kidney, and other organs that put humans' body together.Unlike children who "learn" language faster without any formal teaching and learning process (Sekerina, Fernández, \& Clahsen, 2008, p. vii), language is either consciously learned or subconsciously acquired in adult (Krashen, 1981, p. 1), which generally requires more time and effort to be successful.

Since its first appearance in 1920s, television has been an intimate part of modern life that most people spend their leisure time watching it. Television has also been studied in its relation to children's language development such as a research conducted by Linebarger and Walker (2005) which studies eight different TV programs toward language development of the research subjects, who are fifty one six-months old toddlers. Another study on the influence of subtitled television program on children's incidental foreign-language acquisition is piloted by d'Ydewalle and Van de Poel (1999). In their study, d'Ydewalle and Van de Poel (1999) conducted a study on 8-12 years old Dutch-speaking children by employing a short subtitled cartoon.

Reflecting on those two previous studies, this mini research is aimed at analyzing the effects of a television program on a subject, a two-years-three-months old male child, on his Malay language. The subject regularly watches a movie in Malay language entitled "Upin dan Ipin", 
As one of the basic human properties, people have been interested in studying how language works in the brain as we started to think and consider our lives as human beings (Loritz, 2002, p. 3). Modern research on how human acquire language was initiated approximately 50 years ago, in 1959 to be precise (Cairns, 2008, p. 169) that this field of study needs more explorations. Previously, some philosophersin the $17^{\text {th }}$ century, such as Descartes believed that language was as abstract as angels that its existence was believed, but it was hardly possible to be described. Much older believe on language was also proposed by Aristotle around 300 years BC that instead of believing the brain in which the mind and language was processed, he argued that mind as well as language was processed in the heart(Loritz, 2002, p. 4).

In explaining how human acquire language, Krashen (1982, pp. 9-32) proposes five hypotheses as follow. First, the acquisitionlearning distinction hypothesis. According to Krashen (1982, p. 10), acquisition refers to process in which children develop their first language ability. Learning, on the other hand, belongs to conscious knowledge of a language, which involves learning the rules of a language, and employs those learned language rules in communication.

Second, the natural order hypothesis. This hypothesis claims that human beings acquire the grammatical structures of a particular language in a predictable order. According to Brown (1973 in (Krashen, 1982, p. 12), in English, the most studied language in the world, children initially acquire progressive maker -ing (as in "He is watching TV".) and the plural marker /s/ ("three books") than the third person singular marker /s/ (as in "She eats Hamburger ") and the possessive /s/ ("David's cat").

Third, the Monitor hypothesis. The Monitor hypothesis views that acquisition and learning are employed in very specific ways. Generally, acquisition is responsible for our fluency that it plays a role when we produce a language. Learning, on the other hand, only has one purpose, that is as a Monitor, or editor. Learning is merely responsible to make changes in the form of our utterance, after it is initiated by the acquired system.

Fourth, the input hypothesis. This hypothesis suggests that in order to acquire a language, it is essential for us to understand language that is "a little beyond" our existing language competence. Then, if the language that we already understand is symbolized as $i$, then we would need to understand $i+1$ to be able to acquire a language. In doing so, it would be helpful to employ the context where or in what circumstances the language is spoken, our understanding of the world, or our extralinguistic information.

Fifth, the Affective Filter hypothesis. As its name implies, this hypothesis underlines the importance of affective factors in language acquisition process. There are three categories of affective variables which are widely studied, i.e. (1) Motivation, (2) Self-confidence, and (3) Anxiety.

The curiosity on the developmental stages of language acquisition has encouraged the application of technology in obtaining a more reliable data, one of them is ERP. This event-related brain potentials (ERP) method enables the researchers to examine where the acquisition of language take place in the brain virtually. According to Männel and Friederici (2008), this method employs the data obtained from Electroencephalography (EEG), a technique applied to evaluate voltage fluctuations on the scalp's surface, which is then interpreted to determine language processing in the brain. The finding of a study conducted by Männel and Friederici (2008) reveal that children mostly start identifying word boundaries around their two to five months of age and begin sentence processing as they are thirty two months of age. In their study, they also strongly suggest in employing ERP as a useful research tool in early stages of language learning.

Although viewed as a promising and reliable method in obtaining information about language acquisition, the accessibility as well as the availability of Electroencephalography (EEG) machine which is rare might be a disadvantageous factor in employing it. 
Effect of television program on children's language development. As we see in every house we visit, we hardly find one that has no television. Television has been considered as primary need in our society nowadays. One name behind the invention of this magical box is Vladimir Zworykin as he found the cathode ray tube in 1923 which is used in activating photoelectric cells with moving electrons (Cashmore, 2002, p. 1). Therefore, it would be reasonably appropriate for stating that television is the main devices which shapes and creates the culture of twentieth century because according to Cashmore $(2002$, p. 2), ninety percent of people around the world spend averagely twenty hours in a week for watching television that they eventually exposed on how to act and think according to the television program they watched.

Television provides wide range of programs for its watchers. News, music, documentary, movies and other programs have been designed to accommodate the need of the viewers. In obtaining children's attention, animated program has also been developed and some of them are specifically aimed at assisting children in acquiring foreign languages. Some of those program according to Linebarger and Walker (2005, p. 624) are Dora the Explorer, Blue's Clues, Arthur, Clifford, and Dragon Tales.

Although those programs have colorful characters and backgrounds as well as exciting soundtracks in order to draw children's attention, their effectiveness in assisting language development is still questionable. A longitudinal research conducted by Linebarger and Walker (2005) who investigate the correlation of television viewing and language outcomes on fifty one infants, at the age of six months until they are at thirty months of age, reveals that television programs as listed previously affect children's language in which they increase vocabularies and higher expressive language scores.

Another interesting finding is also reported by d'Ydewalle and Van de Poel (1999). They study 327 children's foreignlanguage acquisition through watching subtitled television programs in the third to sixth grades of a primary school in Dutchspeaking Belgium. They find that there is limited foreign-language acquisition in which the learning of the children was not higher to that ofadults investigated in their prior studies. However, children being studied are reported to acquire more foreign language sound track than in the subtitle.

In addition to those two studies above, Zimmerman, Christakis, and Meltzoff (2007) also study similar issues on children language acquisition and television program. They surveyed 1008 children's parents whose children are two to twenty months old. Employing the MacArthur-Bates Communicative Development Inventory (CDI), they group their finding into two different group of age i.e. infants, children whose age 8 to 16 months, and toddlers, those who age 17 to 24 months. The study concluded that in those two groups, there is no significant correlation between communicative development and media viewing.

\section{METHOD}

This research was aimed at exposing the influence of a particular animated television program in language acquisition which was assessed based on language production. In conducting this study, qualitative method and participant observation were employed wherein the researcher involved in the activity being studied. As its name implies, the observation in this mini research was done in one weekperiod which started from Monday, January $16^{\text {th }}$ to Sunday, January 22 $2^{\text {nd }}, 2017$. Following participant observation method recommended by Larsen-Freeman and Long (2014, p. 60), the data from the study,which were numbered, were collected through diary entries record. Interview, in addition, was also employed to obtain more reliable data.

The subject was a two-yearsthree-months old male child. The subject's mother and people around him speak Bahasa Indonesia to the subject. Therefore, Bahasa Indonesia is viewed as his first language. He was preferred as the research subject due to the prior observation which revealed his interest on watching a particular animated movie in 
Malay language entitled "Upin and Ipin". In addition, based on interview with his mother, the subject has been interesting and watching this program since he was around one year and nine months old. He averagely spends an hour daily in watching it.

As a child whose speech organs are still developing, some of the subject's utterances were not clearly pronounced yet most of the words or sentences were understandable. The data are in form of written data which reveals subject's utterances during the observation.

Although in language academic field the term "speaking" , "utterance" and "talking" are employed for different purposes, for the sake of this study, those two terms are employed interchangeably which refers to the subject's saying during the observation.

\section{RESULT AND DISCUSSION}

This section will discuss the data obtained during one week observation as well as some information about the television program being investigated in this study. Upin dan Ipin, henceforth UDI, is a 3D animated program developed by Les Copaque Production Sdn. Bhd. located in Malaysia. This company was established in December 2005 to develop Malaysia's animation industry and as well as provide opportunities for the Malaysian graduates to exhibit their talent. In Indonesia, UDI is broadcasted by a national television station three times in a dayi.e at 8 a.m., 1 p.m. and at 7.30 p.m. Central Indonesia Time.The identical episode of this television program was broadcasted repeatedly. During the seven days observation, the subject spent 360 minutes in total in watching UDI (see Appendix).

During one week observation, it is discovered that the research subject recognized the characters as well as the objects portrayed in UDI television program as he was noted to exclaim the following utterances by himself while watching it

(1) "main layang-layang mama Upin Ipin" (Mother, Upin and Ipin are playing kite)

(2) "ikan mama ikan" (Mother, there is a fish)

(3) "aduh, jatuhAtok" (Ouch, Atok falls)

(4) "ngaji Upin Upin itu" (Upin and Ipin are reciting Koran)
He was also noted to be capable of answering some questions from his mother while watching it as can be seen from the following dialogs

(5) Mother: "Naik apa si Upin Ipin itu?" (What kind of vehicle do Upin and Ipin use?)

(6) Subject: "Naik motor Upin Upin itu mama" (Upin and Ipin are using motorcycle)

The dialog above happened on the second day of the observation (January $17^{\text {th }}$, 2017) at evening session of UDI program. The scene showed the main characters (Upin and Ipin) were accompanying an older character (Atok) to pick up some Durian fruits on his farm out of their village that they went there by Atok's motorcycle. The subject's mother then asked what kind of vehicle they used. The subject, in his quite clear voice responded it as "a motorcycle"

(7) Mother: "Siapa si itu?" (Who is that?)

Subject: "Opa itu mama" (That is Opa)

This dialog was obtained during the third day of the observation at the evening session of UDI television program as his mother accompanying the subject to watch the movie. She asked who the character talking to Upin and Ipin was. The subject recognized the character asked by his mother as he answered that she was Opa (their grandmother).

Despite the recognition of characters as well as the objects presented on the discussion above, it is revealed that the subject did not produce a lot of utterances which is found in UDI television program. The most spoken utterances from UDI television program repeated by the subjects in his daily talking during the observation were

(8) "ayam goreng", (Fried chicken)

(9) "iyalah" (Alright)

and (9) "yeyeyeye". (Expression of happiness)

"Ayam goreng" is grouped as the data since the subject referred to any chicken, either boiled, grilled, or fried as "ayam goreng" (fried chicken). For different reason, "Iyalah" and "yeyeyeye are viewed as the data. According to the interview, the subject's mother or people around him did not say "iyalah" to 
agree on something or to say "yes"; and they never say "yeyeyeye" for showing happiness. Although there are some other utterances regularly spoken by the characters in UDI, i.e. "betul betul betul" and "ishishish", during the observation the subject was never found to speak such utterances.

The data above show that there is insignificant foreign language production, in this case Malay, employed by the subject in his daily utterances which resemble utterances spoken in his favorite television program. The subject this study therefore can be viewed as confirming previous research conducted by Zimmerman et al. (2007) in which the result reveals the correlation between babies' early videos watching and poor language development.Unfortunately, Zimmerman et al. (2007) does not provide any reason for poor language on those babies in their finding. One quite satisfactory answer for this problem is proposed by American Academy of Pediatrics (APA) (1999), as they state that children around two years old should be discouraged from watching television program as they are in the brain critical period that they require direct interactions with parents and people around them instead of watching television program. Thus, the language input from parents as well as other people is considered as giving more impact on children's language development than the language input from television program.In addition, the negative influence of language development and television viewing is also reported by Anderson and Pempek (2005) as they study the abundant researches dealing with this issue.

The greater impact of older people's input on children's language development compared to that of television was also revealed during the observation. On the fifth day of the observation (January $20^{\text {th }} 2017$ ), the subject's parents took him to attend their family's funeral out of town. One of the subject's female extended family (henceforth is abbreviated as EF) spoke to him and the following dialog occurred.
(10)EF: "Fahri suka susu kotak?" (Do you like milk in the box?)

Subject: "suka" (I do)

EF: "poda ja ro?" (Do you really like it?

(in Bimanese))

Subject: (pauses, look confuse)

EF: "coba bilang poda" (say "I do")

Subject: "poda" (I do)

EF: "suka poda fahri susu kotak?" (Do you realy like milk in the box?)

Subject: "suka poda" (I really like it)

After asking whether the subject liked a box of fresh milk, the EF then checked the subject's liking as she asks "do you really like it?" in Bimanese language. Although the subject looked confuse when listening to this "foreign language", since he never listens such expression before, he was eventually able to use it in his utterance.

Another important factor on this research which is necessary to examine is the television program being studied (Upin dan Ipin) on the subject's language production. As stated previously, Linebarger and Walker(2005) confirm that some television programs promote second language as well as foreign language acquisition. In their research, they verify Dora the Explorer, Blue's Clues, Arthur, Clifford, and Dragon Tales as second and foreign languagepromoting acquisition television programs. Their finding challenges the recommendation from American Academy of Pediatrics (1999) that television programs which are designed to meet the educational curriculum can have beneficial effects on children's language development. Thus, UDI television program may fail to be an "educating" television program in terms of language acquisition since it does not promote foreign language production on subject being studied.

As children are born with different gifts and capacity, the finding of this study cannot be applied to generalize all children's language development since it merely examines one single subject. In addition, time spent on this study may also be another limitation that it might not be adequate to observe the subject's language production. 


\section{CONCLUSION AND RECOMMENDA- TION}

Despite the fact that the subject recognizes the objects as well as characters from the television program being studied in this research, i.e. Upin dan Ipin, it does not give significant effect of the subject's foreign language development that the subject is noted to only employ three utterances from Upin dan Ipin television program in his daily talking.

Since this study is done in limited amount of time and focuses on one subject, it is recommended that another research to study more subjects in a more sufficient time in obtaining rich and fruitful data. In addition, it is also recommended for further research to investigate the effect of time spent of this particular program on children's language development.

As the subject in this study spent 360 minutes in a week, or averagely 51 minutes daily, which is a very little time portion compared to the parents' and other people's interaction, the effect on subject's language development may be different when the time spent on watching the television program is longer.

\section{REFERENCES}

Anderson, D. R., \& Pempek, T. A. (2005). Television and Very Young Children. American Behavioral Scientist, 48(5), 505-522. doi: doi:10.1177/0002764204271506

Cairns, H. S. (2008). Language acquisition research: A peek at the past: A glimpse into the future. In I. A. Sekerina, E. M. Fernández \& H. Clahsen (Eds.), Developmental psycholinguistics: Online methods in children's language processing (Vol. 44). Philadelphia: John Benjamins Publishing.

Cashmore, E. (2002). And there was television: Routledge.

Chomsky, N. (2000). New Horizons in the Study of Language and Mind. New York: Cambridge Univeristy Press.

d'Ydewalle, G., \& Van de Poel, M. (1999). Incidental foreign-language acquisition by children watching subtitled television programs. Journal of Psycholinguistic Research, 28(3), 227-244.

Krashen, S. (1981). Second language acquisition. Second Language Learning, 19-39.

Krashen, S. (1982). Principles and practice in second language acquisition.

Kraus, R. M., \& Chiu, C.-y. (1997). Language and Social Behavior. In D. Gilbert, S. Fiske \& G. Lindsey (Eds.), Handbook of Social Psychology. Boston: McGraw-Hill.

Larsen-Freeman, D., \& Long, M. H. (2014). An introduction to second language acquisition research: Routledge.

Linebarger, D. L., \& Walker, D. (2005). and Toddlers' Television Viewing Language Outcomes. American Behavioral Scientist, 48(5), 624-645. doi: doi:10.1177/0002764204271505

Loritz, D. (2002). How the brain evolved language: Oxford University Press.

Männel, C., \& Friederici, A. D. (2008). Eventrelated brain potentials as a window to children's language processing: From syllables to sentences. In I. A. Sekerina, E. M. Fernández \& H. Clahsen (Eds.), Developmental psycholinguistics: Online methods in children's language processing (Vol. 44). Philadelpia: John Benjamins Publishing.

Media Education. (1999). Pediatrics, 104(2), 341-343.

Sekerina, I. A., Fernández, E. M., \& Clahsen, H. (2008). Developmental psycholinguistics: On-line methods in children's language processing ( Vol. 44). Philadelpia: John Benjamins Publishing.

Upin dan Ipin. (2012). Retrieved January 16, 2017, from http://lescopaque.com/ v10/about.html

Zimmerman, F. J., Christakis, D. A., \& Meltzoff, A. N. (2007). Associations between media viewing and language development in children under age 2 years. The Journal of pediatrics, 151(4), 364-368. 


\section{APPENDIX}

Table 1. Subject's daily time spent in watching Upin dan Ipin television program

\begin{tabular}{cccccc}
\hline \multirow{2}{*}{ No } & \multirow{2}{*}{ Day } & Date & \multicolumn{3}{c}{ Time Spent on Watching UDI (in minutes) } \\
\cline { 3 - 5 } & & Morning & Afternoon & Night \\
\hline 1 & Monday & January 16th, 2017 & - & 30 & 30 \\
2 & Tuesday & January 17th, 2017 & - & 30 & 30 \\
3 & Wednesday & January 18th, 2017 & 30 & - & 30 \\
4 & Thursday & January 19th, 2017 & - & 30 & 30 \\
5 & Friday & January 20th, 2017 & - & - & - \\
6 & Saturday & January 21th, 2017 & - & 30 & 30 \\
7 & Sunday & January 22th, 2017 & - & 30 & 180 \\
\hline
\end{tabular}

Note: (-) symbol indicates that the subject did not watch Upin dan Ipin television program 